\author{
Asian Development Policy Review \\ $\operatorname{ISSN}(e):$ 2313-8343 \\ $\operatorname{ISSN}(p): 2518-2544$ \\ DOI: 10.18488/journal.107.2020.84.288.297 \\ Vol. 8, No. 4, 288-297. \\ (C) 2020 AESS Publications. All Rights Reserved. \\ URL: www.aessweb.com \\ check for
updates
}

\title{
FOREIGN CAPITAL AND DOMESTIC PRODUCTIVITY IN
DEVELOPING COUNTRIES: AN EMPIRICAL ANALYSIS
}

\author{
Fadzli Adam University of Cambridge, U.K. \\ Email:fadzli.adam@gmail.com
}

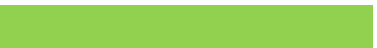

Article History

Received: 14 July 2020 Revised: 17 August 2020 Accepted: 21 September 2020 Published: 30 September 2020

\section{Keywords}

Foreign direct investment Total factor productivity

Human capital

Institutional quality

Developing countrie GMM estimation.

\begin{abstract}
Foreign direct investment (FDI) has originally been regarded as the navigating force of economic activities and economic growth (EG) worldwide, especially in developing countries. The influence of FDI growth on EG involves the absorptive capacities of developing nations. The benefits of FDI can be maximized by enhanced technology transfers and productivity spillover. In this context, the motivation to conduct the current study was to investigate the impact of FDI on the TFP of developing countries, along with the control variables of human capital $(\mathrm{HC})$ and the political institutional (PI) index. As the current study has been conducted in the context of developing countries, the researcher has collected data from world developing indicator (WDI) including Cambodia, Lebanon, Morocco, Malaysia, Thailand, Bahrain, and Cameroon. The panel data was collected from the aforementioned countries over a time period of 30 years. In order to obtain the results, the data were analyzed using the SYS-GMM estimation technique. The findings of the paper indicate that the lagged FDI has a significant impact on TFP, whereas the lagged FDI has an insignificant impact on TFP. The outcome obtained by the application of the interplay term FDI*HC indicated that FDI alone has no direct impact on TFP; however, the impact of the interaction term FDI*HC is positive on TFP. The result obtained by estimating the two interaction terms FDI*HC and FDI*INT collectively suggested that FDI alone has an insignificant influence on TFP; however, the impact of the interaction term FDI*INT on TFP is positive.
\end{abstract}

Contribution/ Originality: This study contributes to existing literature by investigating the impact of FDI on the TFP of developing countries, along with the control variables of human capital (HC) and the political institutional (PI) index.

\section{INTRODUCTION}

Foreign direct investment (FDI) is financing given by a firm or single person in one nation to a business in another region. The FDI procedure starts when a businessperson invests a foreign business in a foreign country (Sunde, 2017). The total factor productivity (TFP) is an evaluation of the order and a description of the finances involved in the change in the transfer of income per-capita (Iamsiraroj, 2016). In the entire production process, this type of foreign investment plays an active role in improving the overall circulation of money within a state, which also helps the state to maintain its economic position (Countries With Most FDI in 2018, 2020). Figure 1 presents a description of the top ten countries with the highest FDI-based inflows in 2017. 


\section{COUNTRIES WITH MOST FDI INFLOWS (\$ BILLION)}

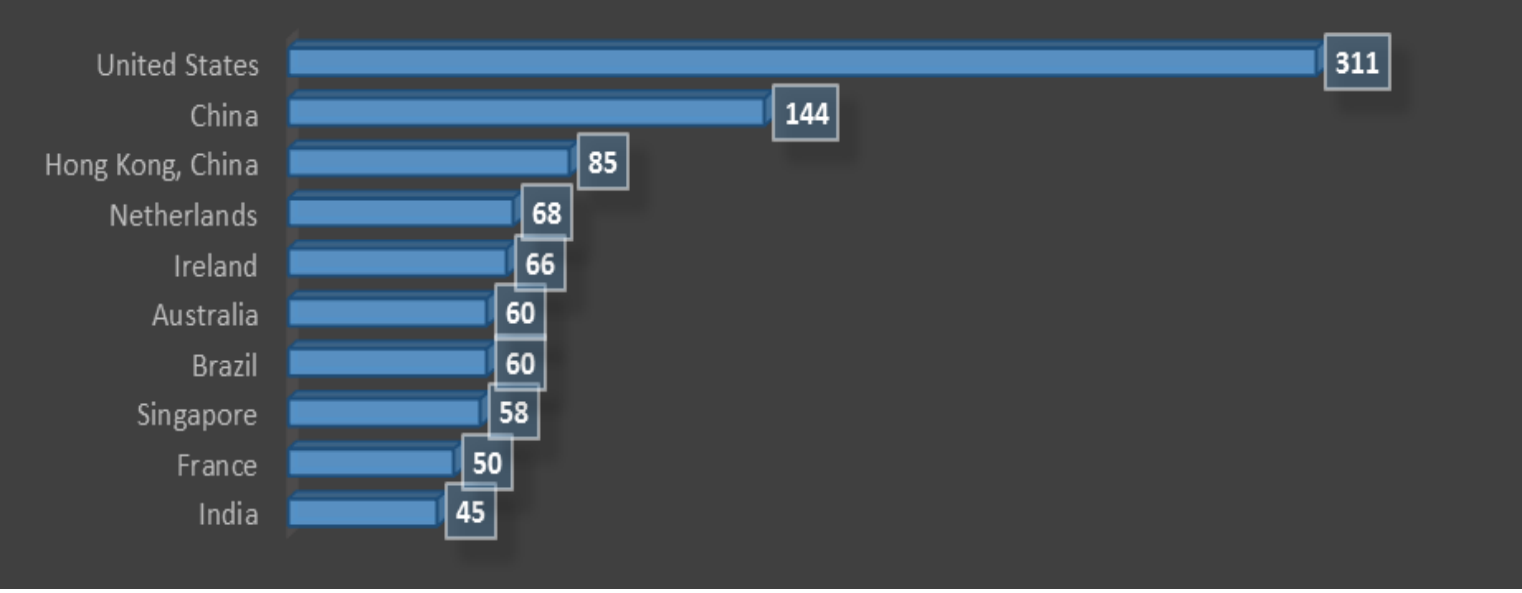

Figure-1. Countries with the most FDI inflows in 2017 (\$ Billion).

The above figure-1 shows that the United States enjoyed the maximum amount of FDI, followed by China. The GDP growth rate of emerging states in 2019 is presented below (Countries With Most FDI in 2018, 2020). The problem statement of this thesis is to empirically evaluate the impact of FDI on domestic productivity by specifically considering the regulatory effect of $\mathrm{HC}$ and PI. This will help to understand how FDI directly enhances the growth rate of raw materials, labor, capital and entrepreneurial activity within a developing state. The major objectives of this research are: to critically inspect the influence of FDI on TFP within developing states and to critical inspect the effect of HC and PI on the relationship between FDI and TFP in a developing region.

This is an advanced and challenging research that fills the gap left by previous research studies, which only discussed the FDI on the EG of a state; for example, Makun, (2018) tested the impact of external factors such as imports, remittances and foreign investment on the EG of the Republic of the Fiji Islands. Empirical analyses have been carried out on Bangladesh's FDI and trade impact on EG (Hussain. \& Haque, 2016), the influence of foreign capital inflow on EG among Asian states (Haq, Anwar, \& Akram, 2017), and the impact of foreign remittances on the domestic capital formation (DCF) in certain African countries (Yiheyis \& Woldemariam, 2016). However, this research certainly left a clear gap with regard to the impact of FDI on the domestic productivity of a developing state, which is covered substantially in this informative paper. All arguments with regard to the thesis statement will be based on authentic values.

When considering the significance of this paper, it becomes clear that this study presents informative and attractive research that provides valid analysis-based outcomes that will help economists, financial policymakers and governments in developing nations to understand the significance of FDI for the development and survival of their nations. Furthermore, this data will motivate them to develop strategies that will directly fulfill the needs and desires of their TFP-based financial growth. This data will be helpful for international and domestic business communities and investors to work towards the expansion of money flow. Finally, economists and business scholars will be able to utilize this data in their own discussions and literature reviews. Section 1 is the introduction of this paper, and it has effectively provided a detailed description of the thesis statement, objectives, justification and significance-based outcomes, in order to present the background of this paper. In Section 2, there will be a brief theoretical literature review of selected variables. The research methodology will be presented in Section 3, based on a discussion on data collection mechanisms and the analytical test description that will be implemented in the results and analysis section. In Section 4, the statistical outcomes of this paper will be interpreted. The final section will present the discussion and analysis, where all the outcomes of this paper will be summarized and concluded. In addition, future implications and limitations will be discussed in this portion. 


\section{LITERATURE REVIEW}

A capital arbitrage theory is a traditional theory of FDI that is based on generating direct investments from low profit-generating states to states where the profitability ratio is much higher. This means that capital is mobile in both international and national markets (Getachew, 2017; Veeramani, Shukla, \& Jamaleh, 2019). However, it is more effective for developed nations to invest in states that have less capital. If there is a connection between the return on capital and long-term interest rates, FDI and the portfolio investments must move in the same direction. This theoretical approach will play a significant role in upgrading the economic performance of a developing state. This theoretical approach has already been utilized by scholars to understand stock market valuations and foreign investments in cross-state development, as well as to consider the influence on the sustainable market performance of underdeveloped and developing nations (Duca \& Ling, 2020; French, 2017; Wang, 2019).

\subsection{Foreign Direct Investment and Total Factor Productivity}

In 2020, Abdullah \& Chowdhury, (2020) studied FDI and TFP. In their paper, they investigated the impact of FDI on the TFP of the receiving country. According to them, enhanced developments provide a structure through which FDI can develop the rate of growth of the receiving nation through the transferals of technology, scattering, and overabundance. Four new TFP series were made for the new development model structures. They also discussed the problem of endogenic systems that use the common method. Their study found no direct association between FDI and TFP. Similarly, Baharumshah, Slesman, \& Devadason, (2017); Pegkas, Staikouras, \& Tsamadias, (2020) similar themes in their research article when investigating the effect of FDI on the growth of TFP. When investigating the impact of FDI on the development of TFP, he examined the role of the main gaps in the country's technology. He concluded that technology is inversely proportional to the impact of FDI on TFP, which means that, with a decrease of the gap, FDI has a direct impact on TFP. Li \& Tanna, (2019) concluded that, in order to acquire production in under-developed countries, the development of organizations is more imperative than the development of human assets.

With his other group members, Ausloos, Eskandary, Kaur, \& Dhesi, (2019); Hong, Sun, \& Huang, (2016) explored the effect of FDI on the TFP of Chinese product industries. In their study, they examined three areas of the forest industry: The timber manufacturing industry, the paper manufacturing industry and its products, and furniture manufacturing. According to this study, FDI is categorized into two major parts: Money from Hong Kong, Macau, and Taiwan (HMT), and money from other non-HMT regions. According to the results, the influence of FDI on TFP in the forest industry is entangled. In HMT areas, FDI has a significant effect on the TFP. However, in non-HMT areas, FDI has a comparatively low effect on TFP (Lin, Du, Dong, Jin, \& Liu, 2020). Desbordes \& Franssen, (2019) discussed the FDI and TFP through an analysis of the carrier sector. They found that FDI has a significant impact on TFP. Through studying these factors in economic and statistical terms, they found that FDI enhances the performance of the receiving country. This growth also increases the TFP of the receiving country. Huang \& Zhang, (2017) have also investigated the importance of FDI on the enhancement of the TFP of production companies in China. In order to do so, they used the PSM method to conclude that the absorption capacity of firms has an important impact on firms; furthermore, product innovation with absorption capacity has a greater impact than other product innovation within a firm. Liang (2017) also investigated the relationship, powers, and domestic company's geophysical positions of FDI that impact technology. In their results, they concluded that FDI positively impacts local and domestic companies and increases their overall productivity. There is also effective productivity between foreign investors and the domestic users (Liang, 2017). The spillover impacts from research and development $(\mathrm{R} \& \mathrm{D})$, foreign activities, and FDI on the TFP of production companies. In many of their empirical outcomes, FDI had a direct and indirect effect on the TFP of Asian production companies. These direct and indirect impacts varied depending on R\&D and foreign activities (Pradeep, Bhattacharya, \& Chen, 2017). In addition to this, Demir \& Su, (2016) investigated the FDI, TFP, and entry barriers into the automotive 
sector in China. They raised three major questions about FDI: The first considered the contrast in the entry barriers of local, foreign, and public money-makers; the second is related to the impacts of TFP on FDI issues; and the third is based on evaluating the impact of justice on the levels of future TFP. Their results showed that foreign money-makers have high entry barriers and a greater impact on TFP levels. Furthermore, FDI positively impacts the future TFP more than other aspects. Hussain (2017) also investigated FDI and its effect on the TFP of Pakistan's local companies. In his research study, he explored seven local companies to examine the data and he adopted a panel data regression. His outcomes suggested that FDI has an impact on the TFP of Pakistan's local companies (Hussain.. 2017).

H1: FDI has a significant impact on TFP.

\section{RESEARCH METHODOLOGY}

Detailed information about the data collection process, the methodology of techniques and tools applied by the researcher, model specifications and measurements of the variables in the study can be found in this section.

\subsection{Data Collection}

As the current study was conducted in the context of developing countries, the researcher collected data from World Development Indicators (WDI) including Cambodia, Lebanon, Morocco, Malaysia, Thailand, Bahrain, and Cameroon. These countries have been selected for data collection because they are very much associated with FDI. The panel data were collected from the aforementioned countries over a time period of 30 years. In terms of data on the variables, the dependent variable, TFP growth, was measured by considering the difference between GDP per capita and physical capital (PC) per capita, as previously discussed. Moreover, the independent variable, FDI, was calculated using the ratio of net FDI to GDP. The control variable, HC, was measured using average years of schooling. The other control variable, PI, was measured using an institutional index developed by past researchers. All data has been collected from very reliable and accurate resources, in order to make sure that the outcomes obtained are authentic and accurate.

\subsection{Total Factor Productivity}

In order to estimate the TFP, the researcher considered the difference between GDP per capita and PC per capita (Bekaert, Harvey, \& Lundblad, 2011). However, HC is not considered for TFP. TFP growth has been measured using the standard model of production function developed by Cobb Douglas, as given below:

$$
Y_{i}=A_{i} K_{i}^{\alpha} L_{i}^{1-\alpha}
$$

In this equation, Y represents the aggregate output, A represents TFP, K represents the PC, and L represents labor. In order to estimate TFP growth, this equation has been changed into a Solow Growth Model (Solow, 1956). In this regard, if the $\alpha$ is considered to be 0.3 , the equation is as follows:

$$
T F P=G R-C A P 0.3
$$

In this equation, GR represents output growth per capita and CAP represents the capital labor ratio.

\subsection{Model Specification}

As the purpose of the study is to find out the impact of FDI on TFP, certain issues must be addressed. The first issue is that some explanatory variables might have endogeneity issues and the second issue is that a case might arise in which productivity is found to impact the FDI of a country in a conflicting manner. In order to resolve these issues, the researcher applied an appropriate technique: SYS-GMM. As the current study involves cross sectional data from developing countries, the SYS-GMM technique has the benefit of being able to deal with the 
country-specific effects, and it can also resolve the biases that may arise due to measurement and correlation errors (Arellano \& Bond, 1991; Blundell \& Bond, 1998). In this way, it can be suggested that TFP growth is impacted by FDI, HC, and PI. Thus, the following model was developed:

$$
T F P_{i t}=\beta_{0} T F P_{i t-1}+\beta_{1} F D I_{i t}+\beta_{2} H C_{i t}+\beta_{3} I N T_{i t}+\mu_{i}+\varepsilon_{i t}
$$

In this equation, TFP is the dependent, FDI is the independent and HC and PI are the control variables. In addition, $\mu_{\mathrm{i}}$ and $\varepsilon_{\mathrm{it}}$ show the country-specific effects and error terms, respectively. In addition to this linear model, there is the possibility that there might be nonlinearities that can be addressed by using interaction factors alongside the control variables. These include FDI*HC and FDI*PI. The direction and magnitude of these impacts can be used to explore the impact of FDI on TFP, which may be either positive or negative. Another issue that might arise, as discussed, is that the FDI and TFP may impact each other in an inverse way. In order to resolve this issue, the researcher has applied a two-step SYS-GMM estimator in the current study. The instruments used include the two-period lagged FDI and the one-period lagged TFP. This two-step estimation has been preferred over the single-step estimation, as the two-step estimation is considered to be more efficient. However, in this type of estimation, there is a chance of bias; however, this can be resolved using standard errors. Before the application of the SYS-GMM estimation, it was necessary to validate the instruments used in the study. In order to do so, the researcher applied the Hansen test, which provides better results if the data is auto correlated and heteroscedastic. Moreover, the autoregressive test has been used to explore the serial correlations between regressions. In this way, the researcher has been able to use this methodology to identify the influence of FDI on the TFP growth in developing countries (Windmeijer, 2005). The GMM estimation equation is given as:

$$
\vartheta_{i t}=\alpha_{i}+\gamma \vartheta_{i, t-1}+\sum_{p=1}^{p} \beta_{p} Z^{p_{i t}}+\sum_{q=1}^{q} \beta_{q} Z^{q} i t+\sum_{r=1}^{r} \beta_{r} Z^{r} i t+\epsilon_{i t}
$$

\section{DATA ANALYSIS}

The findings of the correlations between variables are presented in Table 1, in which it is very clear to see that the variables are significantly correlated. Based on these correlations, the researcher applied the GMM estimation — the results of which will be discussed in detail in this section.

Table-2. Correlation matrix.

\begin{tabular}{c|c|c|c|c}
\hline Variables & TFP & FDI & HC & INT \\
\hline TFP & 1 & & & \\
\hline FDI & $0.625^{*}$ & 1 & & \\
\hline HC & $0.353^{*}$ & $0.532^{*}$ & 1 & 1 \\
\hline INT & $0.721^{*}$ & $0.725^{*}$ & $0.401^{*}$ & \\
\hline
\end{tabular}

If the interactions of $\mathrm{HC}$ and PI are not considered, the relationship between FDI and TFP will be considered as linear. In this regard, the results of the linear relationships are reported in Table 2 of the study. Maximum observations were used in each regression in order to obtain the results. The AR and Hansen test results have been presented, which show that the instruments used in the study are valid and that there are no issues regarding serial correlation in the regressions. In Table 2 , the first column displays HC and the second column displays PI. In the third column, both control variables have been considered. In addition, the next three columns show similar arrangements; however, the difference is that the first lagged value of FDI has been used in the last three columns. It is evident from the Table 2 that the lagged TFP has a positive impact on TFP in all cases; however, this impact is not significant in all cases. Moreover, the impact of FDI on TFP is negative and significant, but the impact of 
lagged FDI on TFP is positive and significant. In addition to these, the control variable HC has been found to have a positive impact on TFP and the PI index also has a positive impact on TFP in the linear model of the study.

Table-3. Linear model.

\begin{tabular}{c|c|c|c|c|c|c}
\hline Variables & $\mathbf{1}$ & $\mathbf{2}$ & $\mathbf{3}$ & $\mathbf{4}$ & $\mathbf{5}$ & $\mathbf{6}$ \\
\hline TFP $(-1)$ & $0.1432^{*}$ & 0.2044 & 0.3736 & $0.2657^{*}$ & 0.1856 & 0.0633 \\
\hline FDI & $-0.2421^{*}$ & $-0.5233^{*}$ & $-0.3643^{*}$ & & & \\
\hline FDI (-1) & & & & $0.4724^{*}$ & $0.3835^{*}$ & 0.1754 \\
\hline HC & 0.0021 & & 0.0272 & 0.0045 & & 0.0062 \\
\hline PI Index & & $0.0055^{*}$ & 0.0122 & & 0.0031 & 0.0072 \\
\hline p-value of AR 1 Test & 0.002 & 0.006 & 0.012 & 0.001 & 0.003 & 0.041 \\
\hline p-value of AR 1 Test & 0.754 & 0.678 & 0.721 & 0.724 & 0.725 & 0.622 \\
\hline p-value of Hansen Test & 0.744 & 0.533 & 0.621 & 0.918 & 0.513 & 0.212 \\
\hline
\end{tabular}

Although HC was found to have no significant impact on TFP, as per Table 2, the interaction between HC and FDI has been used to examine the positive response of TFP on FDI. The results of this interaction are presented in Table 3. The first column presents HC and the second column presents institutions. In the third column, both the control variables have been considered. The table shows that, although FDI has a negative and significant impact on TFP in the presence of control variables, if FDI is taken as the interaction with HC, the impact of this interaction has been found as positive and significant. In the same way, the impact of lagged TFP is also positive. Moreover, the control variable $\mathrm{HC}$ has a positive impact on TFP, and, in the same way, the PI index also has a positive impact on TFP in the case of the FDI*HC interaction. The AR and Hansen test results indicate that the instruments used in this study are valid and there are no issues regarding serial correlations in the regressions.

Table-4. Interaction effect of HC

\begin{tabular}{c|c|c|c}
\hline Variables & $\mathbf{1}$ & $\mathbf{2}$ & $\mathbf{3}$ \\
\hline FDI*HC & $0.5712^{*}$ & $0.7753^{*}$ & 0.3567 \\
\hline TFP (-1) & 0.0765 & $0.1061^{*}$ & 0.0954 \\
\hline FDI & $-0.2725^{*}$ & $-0.1422^{*}$ & -0.2823 \\
\hline HC & $0.2731^{*}$ & & 0.1861 \\
\hline PI Index & & 0.0046 & 0.0132 \\
\hline p-value of AR 1 Test & 0.001 & 0.004 & 0.011 \\
\hline p-value of AR 1 Test & 0.744 & 0.762 & 0.751 \\
\hline p-value of Hansen Test & 0.442 & 0.812 & 0.612 \\
\hline
\end{tabular}

Note: $*, * *$ and $* * *$ depicts $0.01,0.05$ and 0.10 levels of significant respectively.

After incorporating the interaction of $\mathrm{FDI} * \mathrm{HC}$, the researcher used the other interaction term, FDI*INT, in relation with the term $\mathrm{FDI}$ *HC. In addition, it must also be noted that the institutions proxy has been measured using the PI index, in which three components are involved: democracy, rule of law, and the control of corruption. This index ranges from $0-15$, and the higher values represent higher institutional quality. The results of these two interactions are presented in Table 4 of the study. In this case, the impact of the PI index on TFP was not significant, as shown in Table 2. Furthermore, the impact of FDI on TFP is negative; however, when used in interaction with FDI, the interaction had a positive and significant impact on TFP. However, in this case, the impact of the other interaction term, FDI*HC, has become insignificant, as per Table 4. The impact of the lagged TFP was found to be positive as well. The control variable HC has a positive impact on TFP, and, in the same way, the PI index also has a positive impact on TFP in the case of FDI*HC versus FDI*INT interactions in the study See Table 5. Finally, the AR and Hansen test results proved that the instruments used in the current study are valid and there are no issues of serial correlation in the regressions. 
Table-5. Interaction effect of $\mathrm{HC}$ versus institutions.

\begin{tabular}{l|c|c|c}
\hline Variables & $\mathbf{1}$ & $\mathbf{2}$ & $\mathbf{3}$ \\
\hline FDI*INT & & $0.0721^{*}$ & $0.0581^{*}$ \\
\hline FDI*HC & 0.4842 & & 0.8263 \\
\hline TFP $(-1)$ & 0.0556 & $0.1836^{*}$ & 0.0455 \\
\hline FDI & $-0.2701^{*}$ & $-0.1513^{*}$ & -0.2856 \\
\hline HC & $0.2733^{*}$ & & 0.3988 \\
\hline PI Index & & 0.0032 & 0.0266 \\
\hline p-value of AR 1 Test & 0.004 & 0.001 & 0.012 \\
\hline p-value of AR 1 Test & 0.623 & 0.813 & 0.122 \\
\hline p-value of Hansen Test & 0.178 & 0.610 & 0.513 \\
\hline
\end{tabular}

Note: $*, * *$ and $* * *$ depicts $0.01,0.05$ and 0.10 levels of significant respectively.

Lastly, the results of the SYS-GMM estimation are presented in Table 6, according to which all the variables, i.e. FDI, HC and PI, have a significantly positive influence on the TFP. With the increase of one unit of FDI, HC and INT, the TFP was supposed to increase by $36.3 \%, 16.4 \%$ and $26.1 \%$, respectively. The Hansen and SARGAN test values indicate that the instruments used in the study are valid.

Table-6. SYS-GMM

\begin{tabular}{l|c}
\hline Dependent Variable: TFP & SYS GMM Estimation \\
\hline FDI & $0.363^{* *}(0.027)$ \\
\hline HC & $0.164^{* *}(0.0423)$ \\
\hline INT & $0.261^{* *}(0.0172)$ \\
\hline Constant & $4.615(6.614)$ \\
\hline SARGAN Test & $231.42(0.733)$ \\
\hline Arrelano Bond test for AR1 & 0.063 \\
\hline Arrelano Bond test for AR2 & 0.725 \\
\hline Hansen Test for override restrictions & 1.000 \\
\hline
\end{tabular}

Note: *,**and $* * *$ depicts $0.01,0.05$ and 0.10 levels of significant respectively.

\section{DISCUSSION AND CONCLUSION}

The motive to conduct this research was to explore the impact of FDI on the TFP of developing countries and the control variables of $\mathrm{HC}$ and PI. The panel data was collected from certain developing countries and was analyzed using the SYS-GMM estimation technique to obtain certain results. The results indicate that the lagged FDI has a direct impact on TFP; whereas the lagged FDI has a negative impact on TFP. This result can be explained by the fact that the learning and knowledge collected from different sectors and companies of developing countries require certain costs that are accrued from FDIs. Therefore, after such costs are discounted, the influence of FDI on TFP becomes positive; In other words, productivity in the industries increases along with the increase in the FDI. These results are consistent with past research efforts (Liu, 2008; Tanna, Li, \& De Vita, 2018). The next result obtained by the application of the interaction term $\mathrm{FDI} * \mathrm{HC}$ in the regression models of the study indicate that FDI alone has a negative impact on TFP; however, the impact of the interplay term FDI*HC on TFP is positive. This result can be explained because of the fact that, when FDI is invested and used to gain more knowledge and education through new and innovative technologies, this directly results in an increase of productivity. In other words, FDI can be used to improve HC so that TFP can be significantly enhanced. This result is in accordance with similar previous studies (Kose, Prasad, \& Terrones, 2009). The next result was obtained by estimating the two interaction terms, FDI*HC and FDI*INT collectively, which were then applied to the regression models. The verdicts indicate that FDI alone has a negative impact on TFP; however, the impact of the interaction term FDI*INT is positive on TFP. The logical reason behind this is the fact that developing countries require better quality political and governance institutions and rules and regulations, in order to enhance the 
productivity of firms. This result can also be confirmed from past studies (Fousséni, 2018). With regard to the control variables, the results suggest that both the control variables of the study, HC and PI quality, have a favorable impact on TFP, which is also in accordance with previous literature (Afonso \& Jalles, 2016).

Therefore, the findings of the paper indicate that the lagged FDI has a positive impact on TFP, whereas the lagged FDI has a negative impact on TFP. The next result obtained from the application of the interaction term FDI*HC indicates that FDI alone has a negative impact on TFP; however, the impact of the interaction term FDI*HC on TFP is positive. The next result obtained by estimating the two interaction terms, FDI*HC and FDI*INT collectively, suggests that FDI alone has a negative impact on TFP; however, the impact of the interaction term FDI*INT on TFP is positive. Based on these results, it can be concluded that developing states must invest FDI in the improvement of $\mathrm{HC}$ and PI quality in their countries in order to increase TFP.

\subsection{Research Implications}

The current study has practical benefits for governments and policymakers in selected developing countries, as it contains information and guidance about the rational application or utilization of FDI in order to enhance the productivity of firms in these countries. Governments and policymakers must consider information in this study about investing FDI in the improvement of HC and PI quality so that TFP can be increased. In a similar way, this study is useful as researchers can find literature and information about their own research topics, such as the impact of FDI on TFP. They can then apply this information to their own research, although it is recommended that they increase the sample size of their study. In other words, they should consider more countries and a longer data collection time period. Moreover, different panel data estimation techniques could also be used in future studies.

Funding: This study received no specific financial support.

Competing Interests: The author declares that there are no conflicts of interests regarding the publication of this paper.

\section{REFERENCES}

Abdullah, M., \& Chowdhury, M. (2020). Foreign direct investment and total factor productivity: Any nexus? Margin: The Journal of Applied Economic Research, 14(2), 164-190.Available at: https://doi.org/10.1177\%2Fo973801020904473.

Afonso, A., \& Jalles, J. T. (2016). Economic performance, government size, and institutional quality. Empirica, 43(1), 83109.Available at: https://doi.org/10.1007/s 10663-015-9294-2.

Arellano, M., \& Bond, S. (1991). Some tests of specification for panel data: Monte Carlo evidence and an application to employment equations. The Review of Economic Studies, 58(2), 277-297.Available at: https://doi.org/10.2307/2297968.

Ausloos, M., Eskandary, A., Kaur, P., \& Dhesi, G. (2019). Evidence for gross domestic product growth time delay dependence over foreign direct investment. A time-lag dependent correlation study. Physica A: Statistical Mechanics and Its Applications, 527, 121181. Available at: https://doi.org/10.1016/j.physa.2019.121181

Baharumshah, A. Z., Slesman, L., \& Devadason, E. S. (2017). Types of foreign capital inflows and economic growth: New evidence on role of financial markets. Journal of International Development, 29(6), 768-789.Available at: https://doi.org/10.1002/jid.3093.

Bekaert, G., Harvey, C. R., \& Lundblad, C. (2011). Financial openness and productivity. World Development, 39(1), 1-19.Available at: https://doi.org/10.1016/j.worlddev.2010.06.016.

Blundell, R., \& Bond, S. (1998). Initial conditions and moment restrictions in dynamic panel data models. Journal of Econometrics, 87(1), 115-143.Available at: https://doi.org/10.1016/So304-4076(98)00009-8

Countries With Most FDI in 2018. (2020). Global finance.com. Retrieved from https:// www.gfmag.com/topics/macroeconomyand-globalization/countries-most-fdi-inflows-2018. 
Demir, F., \& Su, L. (2016). Total factor productivity, foreign direct investment, and entry barriers in the Chinese automotive industry. Emerging Markets Finance and Trade, 52(2), 302-321.Available at: https://doi.org/10.1080/1540496x.2015.1011519.

Desbordes, R., \& Franssen, L. (2019). Foreign direct investment and productivity: A cross-country, multisector analysis. Asian Development Review, 36(1), 54-79.Available at: https://doi.org/10.1162/adev_a_00123.

Duca, J. V., \& Ling, D. C. (2020). The other (commercial) real estate boom and bust: the effects of risk premia and regulatory capital arbitrage. Journal of Banking $\mathcal{E}^{\circ}$ Finance, 112, 105317.Available at: https://doi.org/10.1016/j.jbankfin.2018.03.006.

Fousséni, N. A. P. O. (2018). Human capital, manufacturing productivity and economic growth in WAEMU countries.

French, J. (2017). Macroeconomic forces and arbitrage pricing theory. Journal of Comparative Asian Development, 16(1), 120.Available at: https://doi.org/10.1080/15339114.2017.1297245.

Getachew, B. (2017). Prospect and challenges of establishment of capital market in Ethiopia. st. Mary's University.

Haq, M., Anwar, N., \& Akram, M. (2017). The impact of foreign capital inflow on economic growth: Empirical evidence from selected Asian countries. Kashmir Economic Review, 26(2), 1-9.

Hlavacek, P., \& Bal-Domanska, B. (2016). Impact of foreign direct investment on economic growth in Central and Eastern European countries. Engineering Economics, 27(3), 294-303.Available at: https://doi.org/10.5755/jo1.ee.27.3.3914.

Hong, J., Sun, X., \& Huang, W. (2016). Local institutions, foreign direct investment and productivity of domestic firms. Review of Development Economics, 20(1), 25-38.Available at: https://doi.org/10.1111/rode.12204.

Huang, Y., \& Zhang, Y. (2017). How does outward foreign direct investment enhance firm productivity? A heterogeneous empirical analysis from Chinese manufacturing. China Economic Reviere, 44, 1-15.Available at: https://doi.org/10.1016/j.chieco.2017.03.001.

Hussain, M. E., \& Haque, M. (2016). Foreign direct investment, trade, and economic growth: An empirical analysis of Bangladesh. Economies, 4(2), 1-14.Available at: https://doi.org/10.3390/economies4020007.

Hussain, A. (2017). Foreign direct investment (FDI) and its impact on the productivity of domestic firms in Pakistan. Pakistan Business Review, 18(4), 792-812.

Iamsiraroj, S. (2016). The foreign direct investment-economic growth nexus. International Review of Economics $\&^{2}$ Finance, 42 , 116-133.Available at: https://doi.org/10.1016/j.iref.2015.10.044.

Kose, M. A., Prasad, E. S., \& Terrones, M. E. (2009). Does openness to international financial flows raise productivity growth? Journal of International Money and Finance, 28(4), 554-580.Available at: https://doi.org/10.1016/j.jimonfin.2009.01.005.

Li, C., \& Tanna, S. (2019). The impact of foreign direct investment on productivity: New evidence for developing countries. Economic Modelling, 80, 453-466.Available at: https://doi.org/10.1016/j.econmod.2018.11.028.

Liang, F. H. (2017). Does foreign direct investment improve the productivity of domestic firms? Technology spillovers, industry linkages, and firm capabilities. Research Policy, 46(1), 138-159.Available at: https://doi.org/10.1016/j.respol.2016.08.007.

Lin, B., Du, R., Dong, Z., Jin, S., \& Liu, W. (2020). The impact of foreign direct investment on the productivity of the Chin ese forest products industry. Forest Policy and Economics, 111, 102035.Available at: https://doi.org/10.1016/j.forpol.2019.102035.

Liu, Z. (2008). Foreign direct investment and technology spillovers: Theory and evidence. Journal of Development Economics, 85(12), 176-193.Available at: https://doi.org/10.1016/j.jdeveco.2006.07.001.

Makun, K. K. (2018). Imports, remittances, direct foreign investment and economic growth in Republic of the Fiji Islands: An empirical analysis using ARDL approach. Kasetsart Journal of Social Sciences, 39(3), 439-447.Available at: https://doi.org/10.1016/j.kjss.2017.07.002.

Ni, B., Spatareanu, M., Manole, V., Otsuki, T., \& Yamada, H. (2017). The origin of FDI and domestic firms' productivityevidence from Vietnam. Journal of Asian Economics, 52, 56-76.Available at: https://doi.org/10.1016/j.asieco.2017.08.004. 
Pegkas, P., Staikouras, C., \& Tsamadias, C. (2020). Does domestic and foreign R\&D capital affect total factor productivity? Evidence from Eurozone countries. International Economic Journal, 34(2), 258-278.Available at: https://doi.org/10.1080/10168737.2020.1734645.

Pradeep, V., Bhattacharya, M., \& Chen, J.-R. (2017). Spillover effects of research and development, exports and foreign investment on productivity: Empirical evidence from Indian manufacturing. Journal of South Asian Development, 12(1), 18-41.Available at: https://doi.org/10.1177/0973174117700467.

Solow, R. M. (1956). A contribution to the theory of economic growth. The Quarterly Journal of Economics, 7O(1), 65-94.Available at: https://doi.org/10.2307/1884513.

Sunde, T. (2017). Foreign direct investment, exports and economic growth: ADRL and causality analysis for South Africa. Research in International Business and Finance, 41, 434-444.Available at: https://doi.org/10.1016/j.ribaf.2017.04.035.

Tanna, S., Li, C., \& De Vita, G. (2018). The role of external debt in the foreign direct investment-growth relationship. International Journal of Finance $\mathcal{E}^{2}$ Economics, 23(4), 393-412.Available at: https://doi.org/10.1002/ijfe.1628.

Veeramani, S., Shukla, A., \& Jamaleh, M. (2019). Financial theories of foreign direct investment: A review of literature. Journal of Industrial and Business Economics, 47, 1-33.

Wang, L. (2019). Stock market valuation, foreign investment, and cross-country arbitrage. Global Finance Journal, 40, 7484.Available at: https://doi.org/10.1016/j.gfj.2018.01.004.

Windmeijer, F. (2005). A finite sample correction for the variance of linear efficient two-step GMM estimators. Journal of Econometrics, 126(1), 25-51.Available at: https://doi.org/10.1016/j.jeconom.2004.02.005.

Yiheyis, Z., \& Woldemariam, K. (2016). The effect of remittances on domestic capital formation in select African countries: A comparative empirical analysis. Journal of International Development, 28(2), 243-265.Available at: https://doi.org/10.1002/jid.3194.

Views and opinions expressed in this article are the views and opinions of the author(s), Asian Development Policy Review shall not be responsible or answerable for any loss, damage or liability etc. caused in relation to/arising out of the use of the content. 